Hadi Peristiwo

\title{
PRESERVASI NASABAH PERBANKAN DALAM MENGGUNAKAN SARANA E-BANKING
}

\begin{abstract}
Abstrak
E-Banking merupakan salah satu pelayanan perbankan tanpa cabang (branchless), yaitu berupa fasilitas yang akan memudahkan nasabah untuk melakukan transaksi perbankan tanpa perlu untuk datang ke kantor di mana suatu bank tersebut berada.

Dalam perkembangan teknologi informasi industri perbankan seperti halnya EBanking, pihak bank harus memperhatikan aspek perlindungan nasabah khususnya keamanan yang berhubungan dengan perlindungan nasabah. Didalam security (keamanan) jaringan on-line E-Banking sendiri terdapat 4 (empat) layanan, yaitu keamanan koneksi nasabah, keamanan data transaksi, keamanan koneksi server serta keamanan jaringan sistem informasi dari server komputer.

Peran tekhnologi informasi dalam dunia perbankan sangatlah mutlak, dimana kemajuan suatu sistem perbankan ditopang oleh peran tekhnologi informasi. Semakin berkembang dan kompleks fasilitas yang diterapkan perbankan untuk memudahkan pelayanan, berarti semakin beragam dan kompleks adopsi tekhnologi yang dimiliki oleh suatu bank.

Implementasi e-banking di Indonesia terbilang cukup sukses. Best practice pada implementasi e-banking di perbankan Indonesia ini tidak lain adalah luasnya penggunaan layanan perbankan berbasis internet pada masyarakat umum.
\end{abstract}

Kata Kunci: Preservasi, nasabah, E-banking.

\section{Pengertian Rahasia Bank}

Fungsi teknologi informasi di dalam industri perbankan merupakan suatu kebutuhan yang sangat diperlukan, dimana perkembangan suatu perbankan harus ditunjang oleh teknologi informasi. Seperti yang diungkapkan oleh seorang futurolog tekhnologi Nicholas Negroponte, bahwa dunia semakin lama semakin digital. Semakin banyaknya fasilitas yang digunakan oleh perbankan untuk memberikan pelayanan kepada nasabah, maka akan semakin kompleks penggunaan tekhnologi informasi yang digunakan serta dimiliki oleh suatu bank. Alasan yang kuat dalam setiap bidang industri termasuk industri yang bergerak dalam bidang perbankan penggunaan teknologi informasi memiliki fungsi dan tujuan untuk dapat memudahkan semua kegiatan operasional baik intern maupun ekstern perbankan, terutama tujuan akhir yang hendak dicapai adalah memuaskan serta memudahkan 
pelayanan kepada nasabah perbankan. Terutama untuk saat ini, hampir semua produk yang dikeluarkan oleh perbankan kepada nasabah memiliki produk yang sama, sehingga tingkat kompetisi antar bank yang terjadi adalah sangat sengit antara satu dengan yang lainnya serta pada akhirnya nanti akan melahirkan berbagai inovasi dan lompatan tekhnologi telematika terutama dibidang perbankan. Serta tuntutan keragaman, kemudahan, kecepatan dan harga jasa yang sangat murah semakin cepat untuk mengemuka.

Salah satu hambatan terbesar yang dihadapi oleh perbankan seiring dengan kemajuan di bidang tekhnologi dan informasi adalah mahalnya serta masih terbatasnya perangkat (tools) tekhnologi tersebut karena masih harus di endorse oleh pihak vendor (penyedia) yang banyak terdapat diluar negeri. Namun hal tersebut tetap menjadi sebuah keharusan bagi perbankan untuk dapat tetap menyediakan karena memiliki fungsi memudahkan, mengefisiensikan serta dapat mengefektifkan kinerja layanan operasional perbankan.

\section{Perbankan Elektronik (E-Banking)}

Mengenai Perbankan Elektronik (E-Banking) yang juga dikenal dengan istilah internet banking adalah kegiatan melakukan transaksi, pembayaran, dan transaksi lainnya melalui hand phone (HP), komputer, laptop / note book maupun Personal Digital Assistant (PDA) dengan website milik bank yang dilengkapi sistem keamanan. E-Banking merupakan salah satu pelayanan perbankan tanpa cabang (branchless), yaitu berupa fasilitas yang akan memudahkan nasabah untuk melakukan transaksi perbankan tanpa perlu untuk datang ke kantor di mana suatu bank tersebut berada. Layanan yang diberikan didalam E-Banking kepada nasabah berupa transaksi pembayaran tagihan, informasi rekening, pemindahbukuan antar rekening, informasi terbaru mengenai suku bunga serta dapat mengetahui nilai tukar valuta asing maupun yang lainnya. Di Indonesia, internet banking telah diperkenalkan pada nasabah perbankan sejak beberapa tahun lalu. Beberapa bank besar baik BUMN atau swasta Indonesia yang menyediakan layanan tersebut antara lain BCA, Bank Mandiri, BNI, BII, Lippo Bank, Permata Bank dan sebagainya.

Kegiatan E-Banking akan mengubah cara bank dalam menjalankan kegiatan operasional perbankan. ${ }^{1}$ E-Banking memungkinkan bagi nasabah untuk dapat melakukan kegiatan-kegiatan pembayaran yang dilakukan secara on-line serta memberikan mediasi kegiatan perbankan melalui jaringan tekhnologi informasi kapan saja dan dimana saja dengan cepat, mudah dan aman karena didukung oleh sistem pengamanan jaringan yang sangat ketat serta dapat berguna untuk menjamin keamanan dan kerahasiaan data serta transaksi yang dilakukan oleh nasabah. Keuntungan lain yang didapatkan adalah bank dapat meningkatkan kecepatan layanan dan jangkauan dalam aktifitas perbankan.

Dalam perkembangan teknologi informasi industri perbankan seperti halnya $E$ Banking, pihak bank harus memperhatikan aspek perlindungan nasabah khususnya keamanan yang berhubungan dengan perlindungan nasabah. Didalam security 
(keamanan) jaringan on-line E-Banking sendiri terdapat 4 (empat) layanan, yaitu keamanan koneksi nasabah, keamanan data transaksi, keamanan koneksi server serta keamanan jaringan sistem informasi dari server komputer.

Menurut pengelompokkannya, e-banking dibagi ke dalam beberapa jenis: ${ }^{2}$

1. Automated Teller Machine (ATM)

Terminal elektronik yang disediakan lembaga keuangan atau perusahaan lainnya yang membolehkan nasabah untuk melakukan penarikan tunai dari rekening simpanannya di bank, melakukan setoran, cek saldo, atau pemindahan dana.

2. Computer Banking

Layanan bank yang bisa diakses oleh nasabah melalui koneksi internet ke pusat data bank, untuk melakukan beberapa layanan perbankan, menerima dan membayar tagihan, dan lain-lain.

3. Debit Card

Kartu yang digunakan pada ATM atau terminal point-of-sale (POS) yang memungkinkan pelanggan memperoleh dana yang langsung didebet (diambil) dari rekening banknya.

4. Direct Deposit

Salah satu bentuk pembayaran yang dilakukan oleh organisasi (misalnya pemberi kerja atau instansi pemerintah) yang membayar sejumlah dana (misalnya gaji atau pensiun) melalui transfer elektronik. Dana ditransfer langsung ke setiap rekening nasabah.

5. Direct Payment (Electronic Bill Payment)

Salah satu bentuk pembayaran yang mengizinkan nasabah untuk membayar tagihan melalui transfer dana elektronik. Dana tersebut secara elektronik ditransfer dari rekening nasabah ke rekening kreditor. Direct payment berbeda dari pre-authorized debit dalam hal ini, nasabah harus menginisiasi setiap transaksi direct payment.

6. Electronic Bill Presentment and Payment (EBPP)

Bentuk pembayaran tagihan yang disampaikan atau diinformasikan ke nasabah atau pelanggan secara online, misalnya melalui email atau catatan dalam rekening bank. Setelah penyampaian tagihan tersebut, pelanggan boleh membayar tagihan tersebut secara online juga. Pembayaran tersebut secara elektronik akan mengurangi saldo simpanan pelanggan tersebut.

7. Electronic Check Conversion

Proses konversi informasi yang tertuang dalam cek (nomor rekening, jumlah transaksi, dll) ke dalam format elektronik agar bisa dilakukan pemindahan dana elektronik atau proses lebih lanjut.

8. Electronic Fund Transfer (EFT)

Perpindahan "uang" atau "pinjaman" dari satu rekening ke rekening lainnya melalui media elektronik

9. Payroll Card 
Salah satu tipe "Stored-Value Card" yang diterbitkan oleh pemberi kerja sebagai pengganti cek yang memungkinkan pegawainya mengakses pembayaraannya pada terminal ATM atau Point of Sales. Pemberi kerja menambahkan nilai pembayaran pegawai ke kartu tersebut secara elektronik.

Saat ini makin banyak bank yang menyediakan layanan internet banking. Hal ini seiring dengan semakin tingginya pengguna internet di dalam negeri. Internet banking akan meningkatkan efisiensi, efektivitas, dan produktivitas sekaligus meningkatkan pendapatan melalui sistem penjualan yang jauh lebih efektif daripada sistem konvensional.

Kenyamanan dan kemudahan yang diberikan internet banking membuat sebagian nasabah perbankan yang telah menggunakan internet banking merasa kurang membutuhkan layanan di cabang (branch). Hal itu ditambah juga dengan penghematan biaya transportasi maupun waktu. Tentu juga didukung dengan fitur internet banking yang semakin komplit saat ini.

Hanya saja, dengan makin maraknya internet banking saat ini, seberapa besar sesungguhnya awareness (tingkat popularitas) dan penetrasi (tingkat penggunaan) nasabah perbankan terhadap salah satu produk electronic banking tersebut dapat diketahui.

Berdasarkan hasil survei MARS ${ }^{3}$ belum lama ini terungkap bahwa dari 1.710 nasabah di 5 kota (Jakarta, Bandung, Semarang, Surabaya, Medan) yang disurvei, sebanyak 34,7\% menyatakan aware atau melek internet banking. Meski jumlah ini masih kalah dibandingkan dengan tingkat awareness mobile banking, tapi sudah ada tren peningkatan yang cukup signifikan.

\section{Grafik-1. Awareness terhadap Internet Banking}

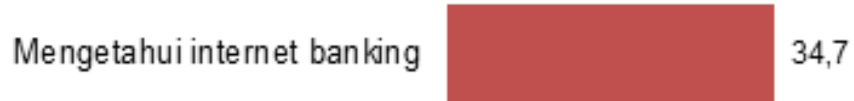

Belum mengetahui internet banking

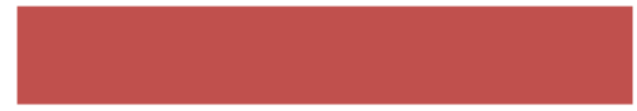

65,3

Sumber: MARS Indonesia

Nasabah di Bandung merupakan nasabah yang paling aware terhadap internet banking dibandingkan kota-kota lainnya, dengan porsi 39,3\%. Disusul tingkat awareness nasabah Jakarta yang beda tipis dengan Bandung (38,9\%). Sedangkan tingkat awareness nasabah di Medan merupakan yang terendah, yaitu hanya $28,6 \%$.

Selanjutnya, dilihat dari sisi status sosial ekonomi (SES), nasabah kelas SES A memiliki tingkat awareness yang lebih baik ketimbang nasabah di SES B. Sedangkan berdasarkan tingkat pendidikan, nasabah berpendidikan tinggi (S1/S2/S3) memiliki 
awareness yang lebih unggul daripada tingkat pendidikan lainnya. Sementara dari sisi usia, nasabah yang paling aware terhadap internet banking adalah pada kelompok usia produktif (25-30 tahun) sebesar 43,1\%. Dan yang paling rendah adalah kelompok usia tua (41-55 tahun) yang baru mencapai 25,6\%.

\section{Tabel-1. Awareness terhadap Internet Banking Berdasarkan Kota, SES, Tingkat Pendidikan dan Kelompok Usia}

Tahu Internet Banking ?

\begin{tabular}{|c|c|c|}
\hline & Mengetahui & Belum mengetahui \\
\hline Total & 34,7 & 65,3 \\
\hline Jakarta & 38,9 & 61,1 \\
\hline Bandung & 39,3 & 60,7 \\
\hline Semarang & 32,5 & 67,5 \\
\hline Surabaya & 32,0 & 68,0 \\
\hline Medan & 28,6 & 71,4 \\
\hline SES [A] & 41,6 & 58,4 \\
\hline SES [B] & 26,3 & 73,7 \\
\hline$\leq S L T A$ & 23,1 & 76,9 \\
\hline Diploma & 43,9 & 56,1 \\
\hline$S_{1} / S_{2} / S_{3}$ & 52,2 & 47,8 \\
\hline $18-24$ tahun & 36,6 & 63,4 \\
\hline $25-30$ tahun & 43,1 & 56,9 \\
\hline $31-34$ tahun & 36,5 & 63,5 \\
\hline 35 - 40 tahun & 39,2 & 60,8 \\
\hline $41-55$ tahun & 25,6 & 74,4 \\
\hline
\end{tabular}

Sayangnya, tingkat awareness internet banking yang sudah lumayan tinggi, tidak diikuti dengan tingkat penetrasinya, yaitu baru mencapai 8,1\%. Masih ada 91,9\% nasabah yang belum menggunakan atau memiliki akun internet banking. Ini 
juga masih jauh lebih rendah dibandingkan dengan tingkat penetrasi mobile banking yang sudah mencapai $41,2 \%$.

Tapi sebenarnya hal ini cukup wajar, mengingat jumlah pengguna handphone atau telepon genggam maupun smartphone yang lebih banyak daripada jumlah pengguna internet, meski belakangan akses internet via handphone (fasilitas data) sudah mulai marak.

Masih rendahnya tingkat penetrasi layanan self service ini, salah satunya karena nasabah belum sepenuhnya merasa aman dari tindak kejahatan ataupun kesalahan sistem internet banking yang merugikan nasabah. Ketertutupan perbankan demi menjaga kredibilitas dan kepercayaan nasabah membuat kasus-kasus perampokan melalui internet banyak yang tidak dilaporkan kepada polisi.

Berdasarkan pantauan ID-SIRTII, upaya gangguan terhadap sistem internet banking bisa mencapai puluhan kali per situs dalam satu hari. Kasus hanya terungkap apabila korban mengumumkan kerugiannya kepada publik.

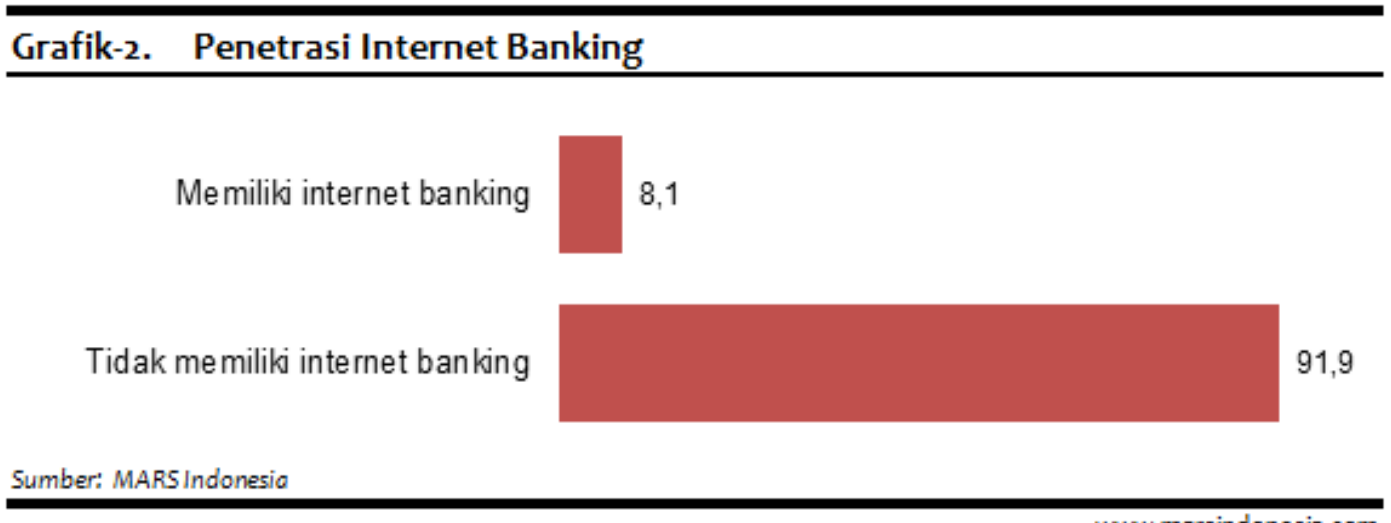

Berdasarkan kota, nasabah di Medan terindikasi memiliki tingkat kepemilikan akun internet banking tertinggi (16,6\%), jauh mengungguli kota-kota lainnya. Di Jakarta sendiri, sebagai pusat pemerintahan dan perekonomian, tingkat penetrasi internet banking baru sebatas 5,8\%.

Selanjutnya dari sisi pendidikan, SES dan usia, terlihat kecenderungan bahwa semakin tinggi tingkat pendidikan, status sosial ekonomi (SES) dan usia (35-40 tahun) nasabah, maka tingkat penetrasi internet banking juga semakin tinggi. 
Sesungguhnya, seiring dengan penetrasi internet dan telepon seluler yang tumbuh dengan sangat cepat di Indonesia, bank perlu mengalokasikan sumber daya tersendiri dan upaya marketing untuk mendorong pertumbuhan penggunaan internet banking di antara nasabah dan calon nasabah yang ada. Tentunya juga diiringi dengan sistem pengamanan dan keamanan yang lebih canggih, sehingga terhindar dari tindak kejahatan dan kesalahan yang merugikan nasabah

\section{Sistem Informasi Perbankan}

Dalam melakukan kegiatannya, perbankan bekerjasama dengan bidang tekhnologi informasi untuk membangun sistem informasi perbankan dengan membuat aplikasi khusus perbankan yang dapat mempermudah semua proses-proses transaksi yang ada pada perbankan dimana salah satunya adalah proses transaksi (input) account.

Merupakan suatu hal sangat relatif bila dikatakan bahwa sebuah aplikasi tekhnologi perbankan itu dikatakan baik atau lebih baik dari aplikasi yang lain. Namun suatu aplikasi yang baik haruslah dapat memenuhi beberapa persyaratan yang penting serta saling berhubungan (connected). ${ }^{4}$

Persyaratan-persyaratan tersebut diantaranya adalah:

1. Sifat operasional aplikasi (product operation)

Untuk dapat memahami dan melihat sifat dan operasional aplikasi dari suatu bank, maka hal-hal yang dapat diukur berhubungan dengan tekhnis analisis perancangan aplikasi, diantaranya yaitu:

a. Correctness: sejauh mana suatu aplikasi memenuhi spesifikasi dan objectivness dari user. Dalam hal ini yang diperhitungkan adalah sejauh mana pengembang sofware perbankan baik internal maupun eksternal dapat mengetahui kebutuhan bisnis bank.

b. Reliability: kemampuan sebuah aplikasi melaksanakan kemampuan sesuai dengan fungsi dan ketelitian yang akurat.

c. Efficiency: seberapa besar kapasitas parameter yang mendukung modul yang saling berkaitan untuk memudahkan user membuat turunan produk, interfacing antar modul serta interfacing terhadap aplikasi lain yang saling dihubungkan untuk mendukung suatu transaksi.

d. Integrity: sejauh mana akses ke aplikasi dan data oleh pihak yang tidak berhak dapat dikendalikan, serta seberapa tinggi akurasi serta tingkat security yang dimiliki.

e. Usability: menunjukkan sejauh mana kemudahan user dari pihak perbankan untuk mempelajari, menggunakan dan mengerti agar output yang dihasilkan dapat lebih optimal.

2. Kemampuan aplikasi dalam menjalani perubahan (product revision). 
Dalam melaksanakan suatu usaha perbankan senantiasa dihadapkan pada perubahan-perubahan baik dari segi strategi maupun perubahan yang diakibatkan oleh regulasi (peraturan). Oleh karena itu maka terdapat beberapa faktor pokok yang harus dipertimbangkan dalam menghadapi perubahan-perubahan tersebut, diantaranya adalah:

a. Maintainability: usaha untuk menemukan perbaikan dari kesalahan (error) maupun usaha untuk melakukan perubahan.

b. Flexibility: usaha yang diperlukan untuk melakukan modifikasi terutama terhadap aplikasi yang berhubungan dengan hal-hal operasional.

c. Testability: usaha yang diperlukan untuk menguji atau memastikan suatu aplikasi apakah telah sesuai dengan kebutuhan bisnis bank serta comply dengan regulasi yang ada atau tidak.

3. Daya adaptasi software terhadap lingkungan baru (product transition).

Perkembangan tekhnologi informasi semakin cepat dan berkembang, perubahan-perubahan terjadi mulai dari operating system yang hampir setiap tahun mengeluarkan versi terbaru, software pendukung, delivery channel serta hardware yang terus dikembangkan untuk mengembangkan aplikasinya sehingga dapat beradaptasi terhadap lingkungan baru.

Delivery channel merupakan salah satu faktor yang harus diperhitungkan dalam pengembangan bisnis dimasa depan, mengingat arah perbankan dunia saat ini adalah menuju sistem cyber banking (bank maya). Untuk mengantisipasi hal tersebut maka perlu dilakukan suatu pengujian terhadap aplikasi yang langsung berhubungan dengan nasabah bank, dalam arti lain adalah apakah aplikasi yang bersangkutan sanggup melakukan hubungan dengan aplikasi lain dalam platform yang berbeda (inter-operability), baik secara langsung maupun melalui perantara perangkat lain (middleware). ${ }^{5}$

Aplikasi transaksi rekening yang terdapat pada perbankan pada umumnya dibuat untuk melakukan pencatatan transaksi itu sendiri. Serta untuk mengelola data yang diperlukan dalam transaksi tersebut agar dapat terkomputerisasi dan lebih akurat sehingga tidak mengalami human error atau redudansi data. Aplikasi tersebut juga didukung oleh tekhnologi internet sehingga dapat diakses secara online oleh petugas (karyawan) bank dibagian-bagian yang bersangkutan.

Dalam bidang pemasaran pun, lembaga perbankan juga membangun suatu web (jaringan) khusus untuk melakukan proses E-Banking yang kesemuanya adalah bertujuan untuk memberikan kemudahan kepada nasabah dalam bertransaksi dan memperoleh informasi mengenai perbankan maupun produk-produk perbankan.

\section{Keuntungan dan Kerugian E-Banking}

Keberadaan e-banking bagi nasabah memberikan keuntungan berupa:

a. Nasabah tidak perlu datang ke bank untuk melakukan transaksi perbankan.

b. Nasabah dapat melakukan transaksi perbankan kapan saja dan dimana saja. 
c. Nasabah dapat menghemat waktu dan biaya perjalanan.

Sedangkan bagi pihak bank, e-banking memberikan keuntungan berupa:

a. Business expansion.

Dahulu sebuah bank harus memiliki sebuah kantor cabang untuk beroperasi di tempat tertentu. Kemudian hal ini dipermudah dengan hanya meletakkan mesin ATM sehingga dia dapat hadir di tempat tersebut. Kemudian ada phone banking yang mulai menghilangkan batas fisik dimana nasabah dapat menggunakan telepon untuk melakukan aktivitas perbankannya. Sekarang ada internet banking yang lebih mempermudah lagi karena menghilangkan batas ruang dan waktu.

b. Customer loyality.

Khususnya nasabah yang sering bergerak (mobile), akan merasa lebih nyaman untuk melakukan aktivitas perbankannya tanpa harus membuka account di bank yang berbeda-beda di berbagai tempat. Dia dapat menggunakan satu bank saja.

c. Revenue and cost improvement.

Biaya untuk memberikan layanan perbankan melalui Internet Banking dapat lebih murah daripada membuka kantor cabang atau membuat mesin ATM.

d. Competitive advantage.

Bank yang memiliki internet banking akan memiliki keuntungan dibandingkan dengan bank yang tidak memiliki internet banking. Dalam waktu dekat, orang tidak ingin membuka account di bank yang tidak memiliki fasilitas Internet Banking.

e. New business model.

Internet Banking memungkinan adanya bisnis model yang baru. Layanan perbankan baru dapat diluncurkan melalui web dengan cepat.

Di sisi lain, fasilitas e-banking pun bisa juga memberikan kerugian bagi nasabah dalam bentuk:

a. Apabila data password tercuri maka dana yang dimiliki akan hilang dan pihak bank tidak bertanggung jawab karena kesalahan berada di nasabah.

b. Apabila nasabah salah transfer maka pihak bank tidak bertanggung jawab karena kesalahan berada di pihak nasabah yang notabene tidak semuanya benar-benar mengerti mengenai proses transfer.

Kerugian yang akan dialami bank jika memanfaatkan fasilitas e-banking diantaranya pengeluaran biaya yang cukup besar untuk meminimalisir resiko dilakukannya pembobolan server bank lewat $e$-banking.

Aplikasi teknologi informasi dalam internet banking akan meningkatkan efisiensi, efektifitas, dan produktifitas sekaligus meningkatkan pendapatan melalui sistem penjualan yang jauh lebih efektif daripada bank konvensional. Tanpa adanya aplikasi teknologi informasi dalam internet banking, maka internet banking tidak akan jalan dan dimanfaatkan oleh industri perbankan. Secara umum, dalam penyediaan layanan internet banking, bank memberikan informasi mengenai produk dan jasanya via portal di internet, memberikan akses kepada para nasabah untuk bertransaksi dan meng-update data pribadinya. 


\section{Ekses Tekhnologi Informasi (E-Banking) Terhadap Perbankan}

Peran tekhnologi informasi dalam dunia perbankan sangatlah mutlak, dimana kemajuan suatu sistem perbankan ditopang oleh peran tekhnologi informasi. Semakin berkembang dan kompleks fasilitas yang diterapkan perbankan untuk memudahkan pelayanan, berarti semakin beragam dan kompleks adopsi tekhnologi yang dimiliki oleh suatu bank.

Penerapan tekhnologi dalam bidang perbankan bertujuan untuk memudahkan operasional intern perusahaan, kemudian juga bertujuan untuk memudahkan pelayanan terhadap nasabah (customers). Layanan ini juga memberikan keuntungan bagi perusahaan perbankan dalam penggunaan sumber daya manusia karena dukungan fasiltas jaringan internet yang menjembatani perbedaan waktu dan tempat dalam transaksi perbankan. ${ }^{6}$ Apalagi untuk keadaan saat ini, khususnya dalam dunia perbankan hampir semua produk yang ditawarkan kepada nasabah hampir semua serupa, sehingga persaingan yang terjadi dalam dunia perbankan adalah bagaimana memberikan produk yang mudah serta cepat. Penerapan suatu tekhnologi informasi menuntut sumber daya manusia yang mampu serta memiliki kompetensi untuk mengaplikasikan tekhnologi informasi tersebut.

\section{Penutup}

Implementasi e-banking di Indonesia terbilang cukup sukses. Best practice pada implementasi e-banking di perbankan Indonesia ini tidak lain adalah luasnya penggunaan layanan perbankan berbasis internet pada masyarakat umum. Dengan sistem keamanan yang mumpuni masyarakat tidak ragu lagi untuk melakukan transaksi melalui media internet ini, baik untuk transaksi dengan nominal kecil sampai dengan nominal besar. Dengan tersedianya akses jaringan internet dewasa ini yang telah mencakup dari kota besar sampai kota-kota kecil di Indonesia membuat penggunaan e-banking berkembang secara signifikan terkait dengan segala kemudahan yang ditawarkan sistem perbankan elektronik ini.

\section{Catatan Akhir:}

${ }^{1}$ Rahmadi, Electronic Banking: Petunjuk Penggunaan Bisnis Perbankan, (Jakarta: Bisnis Publisher, 2010), h. 24.

${ }^{2}$ Gunawan, Bongkar Rahasia E-Banking, (Jogyakarta: Andi Publisher, 2012), h. 54.

3 Training program pada lembaga konsultan MARS dengan tema "E-Banking di Indonesia", pada tanggal 13 Mei 2014.

4 Jayanti, Perlindungan Nasabah Bank Dalam Penggunaan Fasilitas E-Banking, (Bandung: Media Publisher, 2008), h. 45.

${ }^{5}$ Riswandi, Budi Agus, Aspek Hukum Internet Banking, (Jakarta: Rajawali Pers, 2010), h.76.

6 "Internet Banking“" Tak Sepenuhnya Aman. Diakses 28 Maret 2014 di http://bisniskeuangan.kompas.com/ 


\section{DAFTAR PUSTAKA}

Gunawan, Bongkar Rahasia E-Banking, Jogyakarta: Andi Publisher, 2012.

Jayanti, Perlindungan Nasabah Bank Dalam Penggunaan Fasilitas E-Banking, Bandung: Media Publisher, 2008.

Rahmadi, Electronic Banking: Petunjuk Penggunaan Bisnis Perbankan, Jakarta: Bisnis Publisher, 2010.

Riswandi, Budi Agus, Aspek Hukum Internet Banking, Jakarta: Rajawali Pers, 2010, http://bisniskeuangan.kompas.com/

Hadi Peristiwo, dosen pada Fakultas Syari'ah dan Ekonomi Islam IAIN Sultan Maulana Hasanuddin Banten. 